Article

\title{
Centrally Decentralising? Analysing Key Policies and Pathways in Norway's Electricity Transitions
}

\author{
Tor Håkon Jackson Inderberg \\ Fridtjof Nansen Institute, 1326 Lysaker, Norway; E-Mail: thinderberg@fni.no
}

Submitted: 5 February 2020 | Accepted: 9 June 2020 | Published: 11 September 2020

\begin{abstract}
With national electricity systems, 'transition' may involve decentralising production and ownership, and digitalising the system. These processes are facilitated by smart metering, 'prosuming,' and changes in consumer behaviour. Driving factors may be national steering, or the process can be left to the market. In Norway, the government has opted for tightly steered national coordination of three key areas: national smart-meter implementation (since 2011), prosumer regulation (since 2016), and a national end-user demand flexibility regulation (expected to be adopted in 2020). These regulations influence production patterns, energy flows and grid activities. Drawing on organisational fields theory, this article asks: Why was it decided to adopt these policies centrally? Which actors have had greatest influence on policy outputs? And, finally, what of the possible implications? The regulations, developed in a sector in a state of field crisis, have generally been supported by the relevant actors. The Norwegian case can help to explain incumbent roles and field crisis, as well as nuanced drivers in complex transitions, beyond decarbonisation.
\end{abstract}

\section{Keywords}

decentralised energy system; energy transition; organisational field

\section{Issue}

This article is part of the issue "Politics and (Self-)Organisation of Electricity System Transitions in a Global North-South Perspective" edited by Eberhard Rothfuß (University of Bayreuth, Germany) and Festus Boamah (University of Bayreuth, Germany).

(C) 2020 by the author; licensee Cogitatio (Lisbon, Portugal). This article is licensed under a Creative Commons Attribution 4.0 International License (CC BY).

\section{Introduction}

The electricity sector is a crucial area for fulfilling climate targets, along with wider transitions deemed necessary to achieve 'deep decarbonisation,' where the scope of the transition goes well beyond single technologies and sectors, to achieve society-wide and larger-scale emissions reductions (Geels, Sovacool, Schwanen, \& Sorrell, 2017; Schot \& Kanger, 2018; Sovacool \& Walter, 2019). Despite extensive national variations in efforts and results based on factors like historic production portfolios, sector structure and stakeholder interests, and resource endowments, the role of policy has proven important, as have other factors that are shared drivers in these electricity sector transitions (Meadowcroft, 2009; Roberts \& Geels, 2018; Rosenbloom, Haley, \& Meadowcroft, 2018).

Smart electricity meters, prosuming (whereby households and small firms consume and produce electricity), and flexible electricity use at the consumer level all play distinct but interrelated roles in electricity-sector transitions (Ballo, 2015; Inderberg, 2015; Inderberg, Tews, \& Turner, 2018; Skjølsvold, Throndsen, Ryghaug, Fjellså, \& Koksvik, 2018). Energy transition can be understood generally as "change in the composition (structure) of primary energy supply, the gradual shift from a specific pattern of energy provision to a new state of an energy system" (Smil, 2010, p. vii). However, electricity transitions today play out in different ways in connection with various drivers and resistances. Although usually driven by political factors (Moe, 2017), an electricity transition should not be seen as one unified development or direction. It involves interrelated transitions in production and consumption patterns, grid activities, digitalisation of the electricity sector, the electrification of new sectors, and, usually, decarbonisation. Actually, energy transitions should be seen in the plural, embrac- 
ing various trends and directions, involving a range of actors (often with opposing interests) at several levels. This facilitates an understanding of transitions as nonunitary, contested pathways that require analytical disintegration to be comprehended.

Conceptions of energy futures tend to be contested and are influenced by more and less covert interest conflicts. Here I apply an organisational fields perspective to three key policies in order to explain the direction of Norway's ongoing electricity transitions, drawing primarily on data from public policy documents, reports, and hearings. I ask why it was decided to adopt these policies centrally, and which actors have had greatest influence on policy outputs. I also discuss whether there has been a movement from a centralised towards a more decentralised system. The three policies studied here are the adoption of the nation-wide smart meter programme in 2014, the national prosumer regulation from 2016, and the consumer flexibility tariff from 2018 (withdrawn) and 2020 (pending political decision). These policies are arguably among the most important ones of the past 20 years in determining the degree of current and future decentralisation of the Norwegian electricity system. Ever since the early 1900s, Norway has had a traditional electricity system based on publicly owned hydropower; however, it has demonstrated the ability to change and was among the first countries to liberalise its electricity sector in 1991.

Norway has opted for firm political steering of several processes for transitioning its electricity sector, although politically mandating tightly-reined national steering is not warranted. Other countries have chosen various solutions. For example, New Zealand, Sweden, and Switzerland-small countries with a high hydropower share in their electricity mix-have taken differing paths with lighter governmental steering, perhaps with the partial exception of Sweden for smart metering. New Zealand, dominated by hydropower and roughly comparable in size to Norway, has a voluntary, marketbased approach to smart-meter rollout. Sweden had national smart-meter implementation with limited meter functionality in 2009 , followed by a recent renewal of all meters-also politically mandated, and resembling the Norwegian programme. Thus far, Sweden has not mandated an end-user flexibility policy, but the need has been officially recognised. Finally, Switzerland does not have a national programme but has several gridcompany-level programmes for smart metering. These variations in approach warrant closer analysis, where the Norwegian case can shed light on how system structures change and why, in the face of assumed vested interests.

The selected policies all represent key interventions likely to condition future developments relating to the development of the electricity system-in particular, whether or not steps are being taken toward greater decentralisation.

The centralised-decentralised dimension has numerous interpretations (Judson et al., 2020). 'Centralised' and 'decentralised' are often relative and descriptive terms referring to electricity production, grid and consumption structures, and are as such physical-but they can also reflect control over (parts of) the system, ownership, or other aspects (Bauknecht, Funcke, \& Vogel, 2020). Here I relate this dimension primarily to production, energy services and electricity management issues, briefly touching on influence structures. While I do not take a normative stand as to what would represent the 'best' system structure, the policies studied here all enable new balances along this key dimension, and, in my view, represent some movement towards a decentralised system.

\section{Theoretical Perspective and Case Selection}

The organisational field perspective (Fligstein \& McAdam, 2012) is well-suited for shedding light on the interest dynamics within a field or sector. It is useful for explaining changes in dominant interests and perspectives, and ultimately on policy output and institutions (Wooten, 2015).

\subsection{Organisational Fields}

The electricity sector, like any organisational field, is an area of institutionalised life that includes government and industry, as well as other relevant stakeholders (DiMaggio \& Powell, 1983). It is characterised by a shared regulatory framework, as well as relatively consistent patterns of domination and subordination (Scott, 2008). Whereas the regulatory framework may originate from different bodies and levels of administration, an organisational field represents a system of actors, actions, and relations where actors take each another into account as they conduct interrelated and interdependent activities (McAdam \& Scott, 2005). In addition to formal rules and regulations, also shared values, norms, and conventions develop within the field; however, I focus on the formal rules and interests. Many organisations, public as well as private, are involved in operating and governing Norway's energy systems, with actors on the political (ministries, individual politicians) and industrial levels, and NGOs or consumer interests.

Established organisations within the field will often work to keep or enhance inherited formal structures (Thelen \& Streeck, 2005), as it is at the field level that institutions (including regulatory structures) are established, maintained, and changed and disrupted (Lawrence \& Suddaby, 2006). When there is stability, field strategic games are played, to place actors in a favourable future position (Fligstein \& McAdam, 2012). In stable fields, changes are usually incremental, but fields tend to exist in one of three states: emergent, stable, and crisis (Fligstein \& McAdam, 2012). Emergent fields lack institutionalised regulatory and normative structures, and stable fields are more established, with a settled structure. A field crisis typically occurs when es- 
tablished structures, often held in place by incumbent actors, become challenged by external or internal events or new actors, perhaps leading to transitions and new stable states (Koehrsen, 2018). New challenges may include technological developments, external political pressure, internal rising actors, or other pressures currently ongoing in national electricity sectors. It is likely that the three policies studied: a) are shaped in accordance with the incumbent interests in Norway's electricity sector; or b) stem from external or internal events, challenging the established power structures. In the first case, we expect that current incumbents have wanted national policies in the areas analysed here, and have influenced them to secure regulation in accordance with their interest. As the incumbents are dominant actors in control of a traditional electricity system, little change in terms of decentralisation is to be expected. In the second case, the situation can be identified as a field crisis, where challengers to the current structure have had clear influence on policy outcomes. This represents a shift in the sector and may lead to a more decentralised pathway.

\subsection{Case Selection and Empirical Data}

The cases have been chosen because they represent particularly important policies for the centralised/ decentralised dimension of the Norwegian electricity sector. Such official policies or regulations define key premises for subsequent policies, regulations, and sector behaviour, and therefore also pathway direction. Inspired by 'anchoring practices,' the conceptual notion of a hierarchy in practices that 'anchors' and sets premises for other and subsequent practices (Inderberg \& Bailey, 2019; Swidler, 2001), understanding the cases as 'anchoring policies' relates also to their relative place in regulatory complexes, where they strongly shape subsequent regulation. Path change would also entail adaptations in the anchoring policies. The role as dominant premisesetters makes them key arenas for vested interest conflicts within the sector, and useful as analytical units. This means more effective case selection, perhaps at the cost of technical nuances and reduced empirical richness.

The policies for smart metering, prosuming regulation, and demand-side response tariff are related, but separate approaches that all represent such premise-setters. Smart metering enables later possibilities, although their potentials are as yet unrealised. Prosuming-household production of electricity for own use and occasional export of surplus-has been slow to emerge in Norway, but it represents an emerging trend and a possible challenge to the traditional productiongrid-consumption model (Inderberg et al., 2018). Finally, demand-side response in the form of a grid tariff is currently being planned.

This study rests primarily on document studies relating to official reports, academic articles, and official policy documents on the development of the policies under scrutiny. All hearings and hearing statements connected to the development of these policies have been investigated, providing important sources for categorising actor standpoints, actor constellations and contestation of different viewpoints. Individual hearing statements have been collected, processed, and analysed according to views expressed. Given the brief format of this article, the presentation of the hearing statements is necessarily somewhat superficial. For each topic, several hearings have been held, with response submissions ranging from 5 to 84 (see Table 1). In the presentation of the results, I have partially conflated several hearings, narrowing them down to those that led to the final regulation, while still seeking to present differences and developments between the hearings. Narrowing down to the 'most important' hearings (indicated in Table 1) does not mean that small technical changes are necessarily unimportant, but here the focus is on more general trends and viewpoints.

While the implications of any policy can often be interpreted in several ways, and the consequences are not always as intended, the policies selected for analysis here are generally assumed or even officially intended to contribute to greater digitalisation, enabling new technical solutions, facilitating decentralised production of electricity, and encouraging flexibility in electricity consumption. The official policy goals are described under each policy.

In addition to the hearing documents, the data include official reports and legal documents, as well as research literature. The main basis for the analysis is the hearing documents, including the official proposal, hearing letters, and submissions by relevant actors. In principle, any legal entity (including private individuals) may submit hearing responses. Thus, there is some selfselection involved in the empirical material, favouring organisations and individuals with sufficient interest in, competence, and capacity to submit a response.

\section{Three 'Centrally Decentral’ Policies}

Norway's electricity system is already fully renewablesbased. The share of wind power is increasing and is expected to reach $10 \%$ of electricity production by 2021 , with the remainder produced almost exclusively by hydropower. Transnational interconnectors are important for securing supply in years with low precipitation, as well as for export purposes. This leads to a unique situation where the electricity system itself is not in need of decarbonisation, and where stored hydropower provides flexibility. While Norway is not a full member of the EU, it is an EEA member, and must transpose most EU regulations relating to the electricity sector.

Highly visible in the hearings are the traditional electricity-sector actors. The grid utilities-about 130 in Norway-are dominant here, ranging in size from 730,000 end-users and down to fewer than 5,000. The largest companies (Hafslund Nett, Eidsiva Nett, BKK Nett, Agder Energi Nett, Skagerak Energi Nett, Norgesnett) 
Table 1. Hearings: Main elements and overview.

\begin{tabular}{|c|c|c|c|c|}
\hline $\begin{array}{l}\text { Start } \\
\text { hearing }\end{array}$ & Main topic & Specific topic hearing & Responses & $\begin{array}{l}\text { Regulatory } \\
\text { change implemented }\end{array}$ \\
\hline 2008 & Smart metering & $\begin{array}{l}\text { Proposed change in smart-meter } \\
\text { regulation }\end{array}$ & 48 & $\begin{array}{l}\text { Conceptual hearing-no } \\
\text { change planned }\end{array}$ \\
\hline 2009 & Smart metering & $\begin{array}{l}\text { Hearing on the decision await } \\
\text { the European Commission group } \\
\text { M/441 work, to align standards }\end{array}$ & 37 & $\begin{array}{l}\text { Decision to await EU } \\
\text { developments for } \\
\text { standardisation }\end{array}$ \\
\hline $2011 *$ & Smart metering & $\begin{array}{l}\text { Main hearing with proposal for } \\
\text { smart-meter definitions, metering } \\
\text { requirements, billing }\end{array}$ & 65 & Regulations adopted in full \\
\hline 2013 & Smart metering & $\begin{array}{l}\text { Short deadline, proposal to } \\
\text { postpone roll-out }\end{array}$ & 5 & $\begin{array}{l}\text { Two-year postponement of } \\
\text { smart-meter implementation }\end{array}$ \\
\hline $2014 *$ & Prosumer regulation & $\begin{array}{l}\text { Changes in control metering } \\
\text { regulations }\end{array}$ & 46 & $\begin{array}{l}\text { Regulation adopted with } \\
\text { minor modifications }\end{array}$ \\
\hline 2015 & Prosumer regulation & $\begin{array}{l}\text { Additional hearing (short deadline) } \\
\text { on net metering of prosumers for } \\
\text { support scheme }\end{array}$ & 27 & $\begin{array}{l}\text { Regulation withdrawn } \\
\text { following political } \\
\text { instructions from } \\
\text { government }\end{array}$ \\
\hline 2015 & $\begin{array}{l}\text { Flexible tariffs } \\
\text { (demand-side } \\
\text { management) }\end{array}$ & $\begin{array}{l}\text { Conceptual hearing exploring } \\
\text { overarching principles and } \\
\text { potential models }\end{array}$ & 57 & New hearing (as planned) \\
\hline $2018 *$ & $\begin{array}{l}\text { Flexible tariffs } \\
\text { (demand-side } \\
\text { management) }\end{array}$ & $\begin{array}{l}\text { Proposal for tariff model } \\
\text { 'subscribed capacity' }\end{array}$ & 81 & $\begin{array}{l}\text { Proposal withdrawn; new } \\
\text { proposal for hearing in } 2020 \\
\text { (postponed several times) }\end{array}$ \\
\hline 2020 & $\begin{array}{l}\text { Flexible tariffs } \\
\text { (demand-side } \\
\text { management) }\end{array}$ & To be launched & n.a. & \\
\hline
\end{tabular}

Note: * Main policy decision round.

supply the majority of end-users in Norway with electricity, and all these companies have submitted substantial statements to the hearings examined here. The smaller grid companies vary in geographical area and localisation: a bouquet of organisations ranging from those with one or two employees, to larger and more professionalised enterprises (Inderberg \& Løchen, 2012). Energy Norway is the dominant interest organisation, representing some 300 companies that produce, transport or deliver electricity-companies that cover $90 \%$ of Norwegian end-users. Defo is an interest organisation representing producers and grid companies in rural areas, with 68 member companies. Lastly, KS Bedrift represents the municipalities as significant owners of energy companies.

The next actor group is the newer entrants in the electricity sector, with companies like Otovo, Solenergi FUSen, and Solcellespesialisten. These are represented by the interest organisation Norwegian Solar Energy Society (Solenergiforeningen), with about 500 organisational and private individual members. At hearings, these are frequently accompanied by representatives of associ- ations like the interest organisation for electric vehicles, EV Norway. In addition, some of the larger entrepreneurs and housing companies, like the NBBL and OBOS, frequently side with others in this group.

The last group of actors are the NGOs and some consultancy companies. Of the NGOs, Zero, Bellona, and Friends of the Earth Norway have submitted statements to all hearings. Then there are consultancies like Multiconsult, which work to spread information about electricity, control systems, and new modes of production like PV, while also having their own interests.

\subsection{National Smart-Meter Implementation from 2014}

In Norway, smart meters offer two-way communication that measures consumption at regular intervals ( $15 \mathrm{~min}$ utes) and reports hourly. This includes a remote control element, for limiting or shutting off supply (Inderberg, 2015). The meters can provide accurate information to the consumer and billing for real consumption, as well as activation and de-activation of supply; and they can facilitate limited private household generation of elec- 
tricity and feeding into the grid. They are generally seen as a necessary step towards smart grids and effective demand-side management, and as contributing to grid digitalisation, enabling new options for managing consumption patterns and energy services.

Unlike some other countries, including large states under EU regulation like Germany (Meister, Ihle, Lehnhoff, \& Uslar, 2018) and the UK (Sovacool, Kivimaa, Hielscher, \& Jenkins, 2017), Norway has adopted and implemented a complete, nationally-adopted roll-out of smart meters with specific technical requirements, replacing all electricity meters in the country. Here Norway was later than frontrunners like Italy, Sweden, and Finland, but this later adoption enabled coordination with European technical standards for metering. Although these are important markets that the Norwegian electricity sector must relate to (Inderberg, 2015; Zhou \& Brown, 2017), there was significant national room for leeway. Annex I to the Electricity Directive 2009 (which is binding for Norway) requires EU member-states to implement electricity smart meters for $80 \%$ of consumers by 2020 , unless the result of a cost-benefit analysis is negative (EU, 2009). This has led to considerable variation in approaches within the EU in terms of meter requirements, degree of state steering, and meter share of end-users. Norway's smart-meter regulation involved a compulsory rollout for all meters, where technologically advanced minimum requirements and open standards were established for these meters. To date, three brands of meters have been delivered, from the companies Aidon, Kaifa, and Kamstrup.

Prior to the hearings, the Norwegian Water Resources and Energy Directorate (NVE) issued three reports, mapping the feasibility of implementing smart meters (NVE, 2004a, 2004b, 2006). They all concluded that smart metering was not economically feasible. This view had some support among the grid companies, but they were far from unified. Around 2006 the main grid utilities began to favour a national roll-out (Inderberg, 2015), as indicated by a report commissioned by the predecessor to Energy Norway-EBL-which argued that full national implementation could be feasible (ECGroup, 2006). Thereafter, the idea gained political traction.

After further scoping work, four public hearings were held on smart metering: in 2008, 2009, 2011, and 2013and most of the dynamics centred on these. In addition, there have been working groups that included technical experts, often with experience from or representing the electricity sector. The 2008 hearing mapped principles for functionality, financing, and implementation, as well as several other issues (NVE, 2008). The second hearing (NVE, 2009), was held in order to delay certain decisions concerning technical functionality, so as to align with the work of the European Commission in this area. The main hearing was the third one, held in 2011: It decided for full regulation (NVE, 2011b, 2013). The fourth and final hearing concerned postponement of roll-out, but no further changes. Analysis of the three first hearings is included in the empirical material, presented together here for reasons of space.

In all, 65 responses were received to the main hearing in 2011. The majority (40) represented the traditional electricity sector, mainly the grid companies. Submissions also came from meter producers, a few municipalities, and other relevant public actors; likewise from Zero as well as Friends of the Earth, together with Bellona (representing the NGO sector), and from the Association for Electricity-Sensitive Individuals (FELO) (NVE, 2011a). The statements overwhelmingly supported the installation of smart meters, with the clearest exception of FELO. Several actors, including the Consumer Council and the Consumer Association, brought up concerns relating to their areas. Some grid companies queried how to define real-time readings, but no other submissions touched on this.

Several submissions (including those from meter producers) discussed requirements for IP-based communication with external units for feedback to the consumer. In the final regulation, this was altered to not specifying technology for communication, but with a recommendation for open standards. Several submissions-including those from most grid companies, public authorities like the Consumer Council and the Data Protection Agencyfocused on data protection, and on limiting third-party access to data.

Some grid companies (but far from all), as well as the three NGOs, brought up the need for metering prosumergenerated electricity to be exported to the grid. This was supported by some grid companies, whereas others focused on security issues related to this point.

The final regulation requires full national implementation, data measuring enabled for every 15 minutes, actual data measurement every hour, data frequency collection every day, and a physical interface to give instant access to consumption data to the end-user. Meters must also allow remote disconnection and load limitations, and allow for transmission of power prices, tariffs, and steering signals to the consumer (THEMA Consulting Group, 2015b, p. 11).

These were the most important signals from the hearing rounds. However, it should be borne in mind that the full process also involved a series of meetings between the NVE and these actors, primarily regarding the technical scope and implications of the potential design of the regulation (Inderberg, 2015).

\subsection{The Prosumer 2016 Regulation}

Prosuming is frequently seen as a step towards a more decentralised electricity sector (Bauknecht et al., 2020). Until 2010 prosuming was not formally permitted in Norway: Anyone legally producing electricity and feeding into the grid would have to register as a power plant. In 2010 the NVE created exemptions from the metering and control regulations, explicitly opening up for private prosuming (THEMA Consulting Group, 2015b). The stated 
purpose was to acquire experience with prosuming, with the aim of developing a full regulation. The NVE announced a prosumer regulation for hearing in 2014. This involved two hearings, with one following in 2015. The chief topic of the 2014 hearing was the general scheme for prosuming: The main aspects of prosuming, particularly legal definition, tariffing, and access to the green certificates support scheme (NVE, 2016a):

With this proposal, a prosumer was legally understood to be an end user with consumption and production of electricity on the consumer side of the meter, and where the electricity fed exported to the grid at any time does not exceed $100 \mathrm{~kW}$. (NVE, 2014, author's translation)

In addition, a prosumer could not engage in production or trade behind the meter that would require any form of license. Here I focus on the $\mathbf{2 0 1 4}$ hearing, as it largely determined the shape of the regulation.

The 46 submissions were divided on several dimensions. First and foremost, no actors officially opposed the legal opening for prosuming. Energy-sector interest groups and actors, primarily grid companies, were active here.

The most contested area was the definition of 'prosuming' (NVE, 2016a), especially regarding the $100 \mathrm{kWp}$ limit on feed-in capacity. The grid companies as well as Energy Norway, Defo, and KS Bedrift argued that the $100 \mathrm{kWp}$ limit was too high. Energy Norway argued for the limit be lowered to $10 \mathrm{kWp}$, in order to link prosumer activities more closely to private households. Defo argued that some rural grids might not be dimensioned to receive this amount of capacity, whereas KS Bedrift was more open to this arrangement.

On the other side was the broader group consisting of NGOs, entrepreneurs and housing associations, and consultancies/research actors like Multiconsult and NCE Smart Energy Markets. They called for a clearer technical explanation of the need for the $100 \mathrm{kWp}$ limit for qualifying as a prosumer; several actors considered that limit to be arbitrary and wanted it removed. An additional argument was that companies and owners of larger buildings could adapt their systems to this limit, thereby designing economically sub-optimal installations.

Housing association issues were another topic that was mentioned, but only by a few NGOs, some new entrants, entrepreneurs, and Multiconsult. They found it problematic that housing associations should be restricted as regards utilising prosuming as a collective arrangement: In building compounds, each individual flat represents an end-user, but, as shared metering is generally not allowed in Norway, these end-users cannot trade amongst themselves or collectively. This, it was stressed, significantly weakened the potential to expand prosuming within this type of dwelling. That point was not mentioned by the traditional energy actors or their interest organisations.
The last main issue in this hearing concerned cost distribution, relating to the tariff structure. According to the announcement of the hearing for this regulation, consumption from the grid would be priced as for all ordinary consumers. Consumption of self-generated electricity would be 'free': No tax or other charge would apply under the proposed regulation. In addition, prosumers would not have to pay the feed-in grid fee required of ordinary producers.

The rurally focused Defo was critical to exempting prosumers from the feed-in grid fee. Part of the argument concerned the distribution of costs, as prosumers would be exempt from contributing to parts of grid maintenance expenses. That argument has been heard in, for instance, Germany (which has a significantly higher share of prosuming in its system), but was not mentioned by the other hearing partners. No national goals for prosuming were set.

In a Nordic energy market outlook report from 2019, the NVE predicted approximately 7 TWh by 2040 as a realistic potential for solar energy (NVE, 2019). That is the only official prediction of solar potential found.

\subsection{The Power-Based Tariffing (Demand Flexibility) Regulation}

The official goal of demand flexibility is to achieve more effective utilisation of the grid by moving some of the load away from peak times. A tariff structure reflecting power demand (capacity use) over energy (kWh) is often seen as the cornerstone of such regulation. This may be based on various principles, all involving different trade-offs-not discussed here because of space considerations. To date, no detailed regulation for power tariffing has been implemented in Norway, so grid tariffs have been based on energy only (per kWh). Possible models for power-based elements to the tariff (understood as aggregated use by one consumer at any one time, or certain times) include (based on Naper, Haugset, \& Stene, 2016; THEMA Counsulting Group, 2015a):

- Capacity-based tariffs based on the power (in Watts) delivered from the grid. Sub-variants include: subscribed power (where consumers choose their power needs through subscription); actual power use; depending on size of main fuse (in Ampere);

- Time-of-use-where the tariffs vary depending on time: typically the season or time of day;

- System needs/dynamic: tariffs change depending on free capacity in the grid.

These models have different advantages and drawbacks depending on whether the emphasis is put on the ability of the consumer to understand and actively relate to the tariff scheme, or whether it reflects the system needs and represents a fair distribution. The conceptual hearing in 2015 sketched out the above-mentioned concep- 
tual models in three versions, and received inputs on the feasibility of these three, namely: 1) Actual power use; 2) fuse size (Amp) dependent tariff; and 3) subscribed power use. In all, 57 hearing statements were received. Again, these were mostly from grid companies and other traditional electricity-sector actors, along with four private individuals, and with Bellona, Friends of the Earth, and Zero representing the NGO sector. The statements underscored the importance of assessing and modifying the grid tariff structure to reflect power use, and with several alternatives presented for discussion. The grid companies in particular noted that whereas demand for electricity in general had declined slightly, the demand for power-the simultaneous use of electricity in a many locations-was rising. Power use is the deciding factor for grid capacity; the grid companies noted that, as it is expected to rise further, tariffing should reflect the cost structure of the grid (NVE, 2016b).

The main point in many of the hearing statements across a range of actors was the importance of establishing models that are easy for the consumer to understand-in order to achieve the intended effect, and for legitimacy. Many private consumers do not understand the difference between power use (W-the combined electricity use at any given time) and electricity use ( $k W h$-the total number of electricity units consumed). Numerous considerations from the 57 responses discussed aspects of the different models but did little beyond noting the need to link grid development costs, use of power, and consumer tariffs; and that the system must be understandable. Feedback from grid companies supported various models, although most did not favour subscribed power.

The hearing launched in 2017 with a deadline for submissions early 2018 laid out a proposal for a grid tariff based on subscribed capacity. The stated reasons for proposing power-based tariffs were changes in consumption patterns, system needs and not least cost distribution. The proposal described a model of subscribed power where grid tariffs would consist of subscribed effect (W per hour) + power used above subscription ('over use,' at significantly higher cost) + grid loss (usually a default sum) (NVE, 2017). Here 81 statements were submitted-again, mainly from grid companies, with the remainder coming from organisations representing similar actors as in the previous hearings.

All grid companies (except Sognekraft) were highly critical of the proposed model. Their main argument was that it would be too complicated for private consumers to understand-counter to what the NVE held-as well as being seen as undermining the reputation of the grid company as it did not send the right price signal. These arguments were also invoked by many electricity producers and traders.

Consumer groups, new entrants, NGOs and other companies were basically negative, and for the same reasons, although-like the electricity-sector representatives-they supported a general power tariff.
However, the subscribed-effect model was held to need further analysis before possible implementation and was seen as being too complicated for the end-users. The proposal was later withdrawn; a new hearing was scheduled for early 2020, but the results have yet to be evident at the time of writing.

\section{Discussion}

Although electricity production in Norway is fully renewables-based, there are several strong development trends underway. This includes digitalisation and diversification of production-all adding further pressure on the regulatory regime, and with implications for decentralisation. This provides a complex background for the relevant hearings.

According to the organisational field perspective (Fligstein \& McAdam, 2012), increasingly differing interests within the sector and new entrants with additional perspectives and interests indicate a sector in crisis-or at least headed in that direction. In a sector with significant public ownership interests, both today and historically, one could expect more outright or vicarious resistance, whether generally towards state programmes like these three policies, or parts of the policy design. Indeed, there are some elements of resistance as wellfor example, with the contested and (to my knowledge) rather unique regulation of a $100 \mathrm{kWp}$ feed-in limit to the grid for prosuming. Another example involves undermining the power tariff in the shape of resistance, not to the general idea of the tariff, but by various actors involved in the process and most of the proposed solutions in the first hearings. This divergence in the perspectives and apparent interests, and, in the larger picture, support or at least not manifest resistance to the changes, gives further indications of a state of organisational field crisis. This might have involved covert resistance by vicarious means-but in that case, we would expect to find other indications as well, for example practical resistance to prosumer connections to the grid (Inderberg et al., 2018). Notably, the NVE initiatives for a national regulation steering full roll-out of smart meters, detailed prosumer regulation, and demand-side management, were generally supported across the organisations-either because resistance was not deemed feasible or because it was not sufficiently in conflict with sector interests.

This is the main reason why Norway mandated nationally controlled regulations where the alternatives would have been looser regulation, opening up for market-guided implementation of these. Indeed, largescale changes have been implemented before, with the liberalisation of the sector in 1991 (Bye \& Hope, 2002). At the time, new phases of development and economic efficiency reasons were driving factors behind the radical reform, which also brought in new kinds of actors who further boosted the reform (Inderberg, 2011). Today, technological developments, external pressure, and changes within the sector are driving factors for 
the state of crisis. Developments may take various directions in terms of centralisation, control, and market mechanisms-but, together with the NGOs, the new entrants in the electricity sector, representing fewer, more mixed, and smaller companies tend to be more oriented towards decentralisation in various forms.

These actors are challenging established practices with new perspectives and alternative technical expertise, and represent more niche activities by their plural business models relating to smart electricity services, household and company-level distributed production. The greater plurality in submissions in the later hearings than in the earlier ones indicates that they are small but getting stronger. One important area where an explicit stand has been taken concerns allowing prosuming activities in housing associations. As yet, these actors have not achieved full acceptance for their view on shared prosuming activities: Norwegian regulations still stipulate only one meter per end-user, and emplace strict restrictions on prosuming activities from multiple meters. However, the ultimate prosuming regulation can be seen as a success for this group-with some limitations, as sketched out above.

Care should be taken not to interpret the findings as indicating stable and general support from the traditional electricity actors. The centralisationdecentralisation dimension obfuscates important differences in the three policies involved, concerning control over the system decisions, ownership of the system resources, and the physical structure of the system. While the hearings show some general support for steps towards decentralisation, the finer nuances often get lost in the hearing processes. Furthermore, in the Norwegian system with traditionally low electricity prices, weak solar incentives, dominated by flexible hydropower (but with rising shares of wind power, including foreign ownership), a prosuming explosion seems unlikely. Therefore, decentralised production is often not seen as a general threat, even though the NVE projections indicate 'rapid growth of solar,' with up to 7 TWh as a reasonable potential for annual solar production by 2040 , in a system that today produces about 156 TWh in total (NVE, 2019, pp. 4, 21). Even such a level will have an impact on the system.

As to possible pathway directions, all three policies can be said to favour a more decentralised development path. This is true of the smart-meter provision, because it enables digitalisation and greater control over grid management, as well as demand-side responses, storage services, new business models, and new types of collaboration between traditional and new actors (Wadin, Ahlgren, \& Bengtsson, 2017). It also holds true of the prosuming regulation, which opens for more decentralised production and incentivises 'self-consumption'-and lastly, the power tariff, irrespective of the final outcome.

The degree of decentralisation can be evaluated along various dimensions, including physical structure of production and consumption, control, ownership, and/or social aspects (Bauknecht et al., 2020). If poorly designed, the power tariff may discriminate against storage (Newbery, 2018); moreover, it can alienate or empower the end-user, depending on responses. However, the policies studied here seem to provide greater opportunities for third-party actors and new energy service companies. Electricity-consumer flexibility measures link technologies that are key elements in integrating decentralised generation (Judson et al., 2020). Trade-offs are likely here. For example, smart meters provide opportunities for the power-based tariff (THEMA Consulting Group, 2015a), likely to have advantages for the electricity system and cost distribution, but they can negatively influence the profitability of prosuming-at least, without battery storage (Henden et al., 2017).

In sum, the three policies set the direction of digitalisation. This in turn can facilitate various technologies, enabling ordinary members of the public to become prosumers. This again facilitates decentralised production and promotes consumer flexibility as well as the integration of new technologies.

\section{Conclusion: Norway's Electricity-Sector Transitions}

This study has examined why three specific anchoring policies in Norway have been centrally coordinated, what actors have had greatest influence over the policy, as well as discussing possible implications of these regulations for decentralisation of the electricity system. Using an organisational field perspective, I have analysed the official hearing submissions from main actor groups in the official hearings for the smart-meter policy, the prosumer provision, and the peak-power grid tariff scheme.

In accordance with the organisational field perspective, there are clear indications of a system in a state of crisis. A field crisis often occurs when the established structures, held in place by incumbent actors, become challenged by external or internal events or new actors, potentially leading to transitions and new stable states. This is an apt description of the current situation in the Norwegian electricity sector-with pressures from technological developments, developments in neighbouring countries and the EU, and new actor groups in the sector.

The traditionally dominant group of grid companies and their interest organisations certainly still hold key positions. However, their interests, indicated by the hearing submissions for these three policies, have become increasingly less unified since 2011. Higher fragmentation is likely to yield reduced political influence. On the other hand, despite important disparities regarding detailed provisions, the grid companies did endorse the idea of nationally determined regulations, with all three policies. This was an important reason for adoption, with ultimate decision on the power tariff still pending.

By contrast, while new entrants and the NGO group were less influential in the hearings, general portions of the policies under scrutiny do cater to their interests, anchoring developments that move the system toward 
greater decentralisation. More local prosuming, with an expected potential of 7 TWh solar by 2040, is likely to have significant impact on the system. The policies encourage different dimensions of a developmental path relating to digitalisation, production patterns, consumer behaviour, and grid control. Although the policies analysed favour/disfavour further developments toward decentralised production, depending on the details, the findings indicate that the centralisation-decentralisation dichotomy offers a too-blunt perspective, unable to capture the nuances involved. Further elaborating the decentralisation aspects for dimensions like physical structure, ownership, and control may be needed to provide nuancing so that transition pathway directions and their implications become more apparent.

This study of the Norwegian case offers several lessons. First, decentralizing initiatives in the energy system can go hand in hand with centralized political steering. We have seen that nationally mandated initiatives, with general endorsement from the incumbents, have developed digitalisation and prosuming provisions that may lead to increased decentralisation.

Second, this complexity underlines the fact that a rough categorisation of actors into incumbents and new entrants is not sufficiently fine-tuned: analysis of decentralisation requires significantly more refined categorisation and contextualisation to enable more precise predictions.

Last, energy transitions are complex. Transitioning includes several development paths, which may lead to diverging interpretations. Even within the three policy cases examined here, the implications for potential decentralisation developments are manifold, although we may conclude that they represent steps in that direction.

Even in the absence of a driver for decarbonisation (Norwegian electricity production being fully renewables-based), several different transitions are underway. These forces are probably active also in less decarbonized electricity systems. This indicates that even in countries where much of the policy drive is mandated by a decarbonisation goal, more subtle drivers are likely to exist-warranting contextualised, nuanced analysis to clarify the developments and mechanisms influencing these ongoing energy transitions, a keen attention to pathway directionality complexities that includes a deep understanding of inclusion of a variety of relevant actors, and the energy justice implications of the ongoing changes. This article shows that incumbents are involved in driving the transition, but the implications of a more decentralised system for incumbents as well as other stakeholders, requires further investigation.

\section{Acknowledgments}

I would like to Susan Høivik for competent language editing, Torbjørg Jevnaker for input to an early draft, and two anonymous reviewers as well as the thematic issue editors for constructive input. The project was partly funded by Research Council Norway, FME Include, Grant No. 295704.

\section{Conflict of Interests}

The author declares no conflict of interests.

\section{References}

Ballo, I. F. (2015). Imagining energy futures: Sociotechnical imaginaries of the future Smart Grid in Norway. Energy Research and Social Science, 9, 9-20. https:// doi.org/10.1016/j.erss.2015.08.015

Bauknecht, D., Funcke, S., \& Vogel, M. (2020). Is small beautiful? A framework for assessing decentralised electricity systems. Renewable and Sustainable Energy Reviews, 118, 109543. https://doi.org/10.1016/ j.rser.2019.109543

Bye, T., \& Hope, E. (2002). Electricity market reform: The Norwegian experience. In L. Sørgard (Ed.), Competition and welfare: The Norwegian experience. Oslo: Konkurransetilsynet.

DiMaggio, P. J., \& Powell, W. W. (1983). The iron cage revisited: Institutional isomorphism and collective rationality in organizational fields. American Sociological Review, 48(2), 147-160.

ECGroup. (2006). Toveiskommunikasjon: Status, muligheter og tiltak i Norge [Two-way communication: Status, options, and measures in Norway]. Trondheim: ECGroup.

European Union. (2009). Directive 2009/72/EC of the European Parliament and of the Council of 13 July 2009 concerning common rules for the internal market in electricity and repealing Directive 2003/54/EC (Text with EEA relevance) (Document 32009L0072). Brussels: European Commission.

Fligstein, N., \& McAdam, D. (2012). A theory of fields. Oxford: Oxford University Press.

Geels, F. W., Sovacool, B. K., Schwanen, T., \& Sorrell, S. (2017). Sociotechnical transitions for deep decarbonization. Science, 357(6357), 1242-1244. https:// doi.org/10.1126/science.aao3760

Henden, L., Ericson, T., Audun Fidje, J., Fonneløp, E., Isachsen, O., Skaansar, E., \& Spilde, D. (2017). Batterier i bygg kan få betydning for det norske kraftsystemet [Battery storage in buildings may have consquences for the Norwegian electricity system]. Oslo: Norwegian Water Resources and Energy Directorate.

Inderberg, T. H. J. (2011). Institutional constraints to adaptive capacity: Adaptability to climate change in the Norwegian electricity sector. Local Environment, 16(4), 303-317. https://doi.org/10.1080/13549839. 2011.569538

Inderberg, T. H. J. (2015). Advanced metering policy development and influence structures: The case of Norway. Energy Policy, 81, 98-105. https://doi.org/ 10.1016/j.enpol.2015.02.027

Inderberg, T. H. J., \& Bailey, I. (2019). Changing the 
record: Narrative policy analysis and the politics of emissions trading in New Zealand. Environmental Policy and Governance, 29(6), 409-421. https://doi.org/ 10.1002/eet.1868

Inderberg, T. H. J., \& Løchen, L. A. (2012). Adaptation to climate change among electricity distribution companies in Norway and Sweden: Lessons from the field. Local Environment, 17(6/7), 663-678. https:// doi.org/10.1080/13549839.2011.646971

Inderberg, T. H. J., Tews, K., \& Turner, B. (2018). Is there a prosumer pathway? Exploring household solar energy development in Germany, Norway, and the United Kingdom. Energy Research \& Social Science, 42, 258-269. https://doi.org/10.1016/j.erss.2018.04. 006

Judson, E., Fitch-Roy, O., Pownall, T., Bray, R., Poulter, H., Soutar, I., . . Mitchell, C. (2020). The centre cannot (always) hold: Examining pathways towards energy system de-centralisation. Renewable and Sustainable Energy Reviews, 118, 109499. https://doi. org/10.1016/j.rser.2019.109499

Koehrsen, J. (2018). Exogenous shocks, social skill, and power: Urban energy transitions as social fields. Energy Policy, 117, 307-315. https://doi.org/10.1016/ j.enpol.2018.03.035

Lawrence, T. B., \& Suddaby, R. (2006). Institutions and institutional work. In S. R. Clegg, C. Hardy, T. B. Lawrence, \& W. R. Nord (Eds.), The Sage handbook of organization studies (2nd ed., pp. 215-254). London: Sage.

McAdam, D., \& Scott, R. W. (2005). Organizations and movements. In G. F. Davis, D. McAdam, W. R. Scott, \& M. N. Zald (Eds.), Social movements and organization theory (pp. 4-40). https://doi.org/10.1017/ CBO9780511791000.003

Meadowcroft, J. (2009). What about the politics? Sustainable development, transition management, and long term energy transitions. Policy Sciences, 42(4), 323-340. https://doi.org/10.1007/s11077009-9097-z

Meister, J., Ihle, N., Lehnhoff, S., \& Uslar, M. (2018). Smart grid digitalization in Germany by standardized advanced metering infrastructure and green button. In L. A. Lamont \& A. Sayigh (Eds.), Application of smart grid technologies: Case studies in saving electricity in different parts of the world (pp. 347-371). https://doi.org/10.1016/b978-0-12803128-5.00010-6

Moe, E. (2017). Does politics matter? Explaining swings in wind power installations. AIMS Energy, 5(3), 341-374.

Naper, L. R., Haugset, A. S., \& Stene, M. (2016). Innføring av effekttariffer i distribusjonsnettet-et forklaringsproblem? [Implementation of power tariffs in the distribution grid-An explanation problem?]. Oslo: Norwegian Water Resources and Energy Directorate. Retrieved from https://tfou.no/wp-content/ uploads/2016/11/rapport2016_86.pdf
Newbery, D. (2018). Shifting demand and supply over time and space to manage intermittent generation: The economics of electrical storage. Energy Policy, 113, 711-720. https://doi.org/10.1016/j.enpol.2017. 11.044

Norwegian Water Resources and Energy Directorate. (2004a). Kartlegging av bruk og nytte av toveiskommunikasjon i Norge [Mapping of use and usefullness of two-way communication in Norway]. Oslo: Norwegian Water Resources and Energy Directorate.

Norwegian Water Resources and Energy Directorate. (2004b). Toveiskommunikasjon i det norske kraftmarkedet? Er det hensiktsmessig med tiltak fra myndighetene for å fremskynde en utbygging? [Two-way communication in the Norwegian electricity market? Is it appropriate to adopt measures to expedite implementation?]. Oslo: Norwegian Water Resources and Energy Directorate.

Norwegian Water Resources and Energy Directorate. (2006). Automatisk måleravlesning og toveiskommunikasjon. Styringsinstrument eller avlesningsautomat? [Automatic meter reading and two-way communication. Steering instrument or reading machine?]. Oslo: Norwegian Water Resources and Energy Directorate.

Norwegian Water Resources and Energy Directorate. (2008). Avanserte måle-og styringssystem (AMS). Forslag til endringer i forskrift 11. mars 1999 nr. 301. Høringsdokument oktober 2008 [Advanced metering system. Proposal for changes in Regulation 11 March 1999 no. 301. Hearing document October 2008]. Oslo: Norwegian Water Resources and Energy Directorate.

Norwegian Water Resources and Energy Directorate. (2009). Avanserte måle-og styringssystem (AMS) Forslag til endringer i forskrift 11. mars 1999 nr. 301. Tilleggshøring 2009 [Advanced metering system. Proposal for changes in Regulation 11 March 1999 no. 301. Additional hearing 2009]. Oslo: Norwegian Water Resources and Energy Directorate.

Norwegian Water Resources and Energy Directorate. (2011a). Avanserte måle-og styringssystem (AMS) Tilleggshøring 2009. Høringsuttalelser med NVE sine kommentarer [Advanced metering system. Additional hearing 2009. Hearing statements with NVE responses]. Oslo: Norwegian Water Resources and Energy Directorate.

Norwegian Water Resources and Energy Directorate. (2011b). Avanserte måle-og styringssystemer. Høringsdokument februar 2011 [Advanced metering system. Hearing document February 2011]. Oslo: Norwegian Water Resources and Energy Directorate.

Norwegian Water Resources and Energy Directorate. (2013). Oppsummeringsdokument: Endring i avregningsforskriften-AMS [Summary document: Changes in metering regulation-Advanced meters]. Oslo: Norwegian Water Resources and Energy Directorate. 
Norwegian Water Resources and Energy Directorate. (2014). Forslag om endring av kontrollforskriften og avregningsforskriften vedrørende plusskundeordning [Proposal for changes in control and metering regulation regarding prosuming]. Oslo: Norwegian Water Resources and Energy Directorate. https://doi. org/10.13765/j.cnki.cn11-4467/g2.2012.01.016

Norwegian Water Resources and Energy Directorate. (2016a). Endringer i kontrollforskriften vedrørende plusskundeordningen. Oppsummering av høringsuttalelser og endelig forskriftstekstoppsummering av høring og ny forskriftstekst [Changes in control and metering regulation regarding prosuming. Summary of hearing submissions and final regulation]. Oslo: Norwegian Water Resources and Energy Directorate. Retrieved from http://publikasjoner.nve.no/ rapport/2016/rapport2016_47.pdf

Norwegian Water Resources and Energy Directorate. (2016b). Oppsummeringsrapport: Høring om tariffer for uttak i distribusjonsnettet. Oppsummering av høringsuttalelser [Summary report: Hearing of tariffs for electricity use from the distribution grid]. Oslo: Norwegian Water Resources and Energy Directorate.

Norwegian Water Resources and Energy Directorate. (2017). Forslag til endring i forskrift om kontroll av nettvirksomhet. Utforming av uttakstariffer $i$ distribusjonsnettet [Proposal for changes in regulation for controll of grid activities. Design of tariffs for electricity use from the distribution grid]. Oslo: Norwegian Water Resources and Energy Directorate. Retrieved from http://webfileservice.nve.no/ API/PublishedFiles/Download/201706767/2242754

Norwegian Water Resources and Energy Directorate. (2019). Kraftproduksjon i Norden til 2040 [Power production in the Nordics up to 2040] (Norwegian Water Resources and Energy Directorate Report No. 43/19). Oslo: Norwegian Water Resources and Energy Directorate. Retrieved from http://publikasjoner.nve.no/ rapport/2019/rapport2019_43.pdf

Roberts, C., \& Geels, F. W. (2018). Conditions for politically accelerated transitions: Historical institutionalism, the multi-level perspective, and two historical case studies in transport and agriculture. Technological Forecasting \& Social Change, 140, 221-240. https://doi.org/10.1016/j.techfore.2018.11.019

Rosenbloom, D., Haley, B., \& Meadowcroft, J. (2018). Critical choices and the politics of decarbonization pathways: Exploring branching points surrounding low-carbon transitions in Canadian electricity systems. Energy Research and Social Science, 37, 22-36. https://doi.org/10.1016/j.erss.2017.09.022

Schot, J., \& Kanger, L. (2018). Deep transitions: Emergence, acceleration, stabilization and directionality. Research Policy, 47(6), 1045-1059. https://doi.org/ 10.1016/j.respol.2018.03.009

Scott, W. R. (2008). Institutions and organizations: Ideas and interests (3rd ed.). Thousand Oaks, CA: Sage.

Skjølsvold, T. M., Throndsen, W., Ryghaug, M., Fjellså,
I. F., \& Koksvik, G. H. (2018). Orchestrating households as collectives of participation in the distributed energy transition: New empirical and conceptual insights. Energy Research and Social Science, 46, 252-261. https://doi.org/10.1016/j.erss.2018.07. 035

Smil, V. (2010). Energy transitions: History, requirements, prospects. Santa Barbara, CA: ABC-CLIO. Retrieved from http://library.aceondo.net/ebooks/HISTORY/ Energy_Transitions_History_Requirements_ _Prospects.pdf

Sovacool, B. K., Kivimaa, P., Hielscher, S., \& Jenkins, K. E. H. (2017). Vulnerability and resistance in the United Kingdom's smart meter transition. Energy Policy, 109, 767-781. https://doi.org/10.1016/j.enpol. 2017.07.037

Sovacool, B. K., \& Walter, G. (2019). Internationalizing the political economy of hydroelectricity: Security, development and sustainability in hydropower states. Review of International Political Economy, 26(1), 49-79. https://doi.org/10.1080/ 09692290.2018 .1511449

Swidler, A. (2001). What anchors cultural practices. In T. Schatzki, K. Knorr Cetina, \& E. Von Savigny (Eds.), The practice turn in contemporary theory (pp. 83-101). Retrieved from https://conceptsinsts.wiki spaces.com/file/view/PracticeTurnInContemporary Theory.pdf

Thelen, H., \& Streeck, W. (2005). Introduction: Institututional change in advanced political economies. In $\mathrm{H}$. Thelen \& W. Streeck (Eds.), Beyond continuity: institutional change in advanced political economies (pp. 1-39). Oxford: Oxford University Press.

THEMA Consulting Group. (2015a). Kommentar til NVEs konsepthøring om tariffer i distribusjonsnettet [Comments for NVEs conceptual hearing about tariffing in the distribution grid]. Oslo: THEMA Consulting Group.

THEMA Consulting Group. (2015b). Rules and regulation for demand response and micro-production. Oslo: THEMA Consulting Group.

Wadin, J. L., Ahlgren, K., \& Bengtsson, L. (2017). Joint business model innovation for sustainable transformation of industries: A large multinational utility in alliance with a small solar energy company. Journal of Cleaner Production, 160, 139-150. https://doi.org/ 10.1016/j.jclepro.2017.03.151

Wooten, M. E. (2015). Organizational fields. In International encyclopedia of the social \& behavioral sciences: Second edition (2nd ed., Vol. 17, pp. 375-378). https://doi.org/10.1016/B978-0-08097086-8.73120-5

Zhou, S., \& Brown, M. A. (2017). Smart meter deployment in Europe: A comparative case study on the impacts of national policy schemes. Journal of Cleaner Production, 144, 22-32. https://doi.org/10.1016/ j.jclepro.2016.12.031 


\section{About the Author}

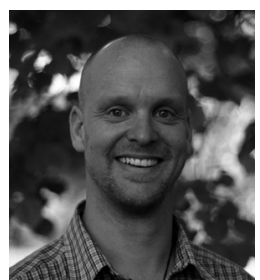

Tor Håkon Jackson Inderberg (PhD) is a Senior Research Fellow in the Fridtjof Nansen Institute outside of Oslo, Norway. As a Political Scientist he focusses on energy and climate policies and has published on a variety of issues that falls under the topics of climate policy, energy policy, and low carbon-transitions; including issues relating to local energy production, renewables support schemes, emissions trading, end-user and metering policies, climate change adaptation, and renewable energy licensing systems. 